\title{
PELATIHAN, PEMBIMBINGAN PTK DAN PUBLIKASI ILMIAH GURU-GURU SMA NEGERI 7 PEKANBARU
}

\author{
Rahmiwati Hilma*, Prasetya, Hasmalina Nasution, Rahmadini Syafri, Fitra \\ Perdana, Jufrizal Syahri, Sri Hilma Siregar \\ Program Studi Kimia, Fakultas MIPA dan Kesehatan \\ Universitas Muhammadiyah Riau \\ email: hilma75@yahoo.com
}

\begin{abstract}
Scientific writing training was one of the efforts to develop the profession of high school teachers $N 7$ Pekanbaru. The training aims to equip high school teachers of $N 7$ Pekanbaru in terms of strategizing the scientific papers correctly according to the writing guidelines, and equip the teachers in the scientific writing publication procedures in the journal. The training method is the percentage of resources, discussion and simulation of papers that have been prepared by the trainees. The lecture method is necessary to explain the procedures of scientific writing, including how to arrange class action research into a scientific work. The exercise/practice method is required to give participants a scientific writing for the journal article. This scientific writing training activity in its entirety can be said to be seen from the achievement of the target participants, the achievement of training objectives, the achievement of planned target material, and the ability of participants in Material. The supporting factors in this community service activities are the availability of experts who are imported to the training in SMA N 7 Pekanbaru, participant enthusiasm, the support of the school principal, and the supporting fund of the university. The Output of this activity is expected to have several teacher papers (participants) in the form of journals and proceeding that are ready to be submitted to the relevant journal.
\end{abstract}

Keywords: scientific writings, scientific publications, teacher profession development

\begin{abstract}
Abstrak
Pelatihan penulisan karya tulis ilmiah merupakan salah satu upaya untuk pengembangan profesi guru-guru SMA N 7 Pekanbaru. Pelatihan ini bertujuan untuk membekali guru-guru SMA N 7 Pekanbaru dalam hal strategi menyusun karya tulis ilmiah secara benar sesuai dengan pedoman penulisan, dan membekali guru dalam prosedur publikasi karya tulis ilmiah dalam jurnal. Metode pelaksanaannya adalah persentasi oleh narasumber, diskusi dan simulasi makalah yang sudah dipersiapkan peserta pelatihan. Metode ceramah diperlukan untuk menjelaskan prosedur penyusunan karya tulis ilmiah, termasuk di dalamnya bagaimana menyusun penelitian tindakan kelas menjadi sebuah karya tulis ilmiah. Metode latihan/praktik diperlukan untuk memberi kesempatan kepada peserta menulis karya tulis ilmiah berupa artikel untuk jurnal. Kegiatan pelatihan penulisan karya tulis ilmiah ini secara keseluruhan dapat dikatakan baik dilihat dari ketercapaian target peserta pelatihan, ketercapaian tujuan pelatihan, ketercapaian target materi yang direncanakan, dan kemampuan peserta dalam penguasaan materi. Faktor pendukung terlaksananya kegiatan Pengabdian Masyarakat ini adalah ketersediaan tenaga ahli yang didatangkan untuk pelatihan di SMA N 7 Pekanbaru, antusiasme peserta, dukungan kepala sekolah tempat penyelenggaraan, dan dana pendukung dari universitas. Output dari kegiatan ini diharapkan adanya beberapa makalah guru (peserta) dalam bentuk jurnal dan prosiding yang siap untuk disubmit ke Jurnal yang relevan.
\end{abstract}

Kata kunci: karya tulis ilmiah, publikasi ilmiah, pengembangan profesi guru 


\section{PENDAHULUAN}

Membuat karya tulis ilmiah merupakan salah satu tugas yang harus dipenuhi oleh para guru SMA sebagai persyaratan peningkatan jenjang karir mereka. Namun, setakat ini, penulisan karya ilmiah masih sering menjadi beban bagi para guru karena keterbatasan pengetahuan mereka tentang teknis penulisan ilmiah. Akibatnya, karya ilmiah yang mereka hasilkan seringkali belum sesuai dengan kaidah penyusunan karya ilmiah. Bahkan, banyak dijumpai karya ilmiah yang sarat dengan plagiasi. Berdasarkan hal tersebut, kami merasa perlu memfasilitasi para guru SMA dengan memberikan pelatihan penulisan karya ilmiah dan strategi menghindari plagiasi agar hasil tulisan mereka dapat memenuhi standar keilmuan.

Seperti diketahui bersama TUPOKSI Guru adalah bidang: Pendidikan, Proses pembelajaran, Pengembangan profesi dan Penunjang proses pembelajaran.

Untuk meningkatkan wawasan guru-guru SMA Negeri 7 Pekanbaru, maka salah satu cara yang dapat dilakukan adalah dengan melakukan Pelatihan Pembimbingan Pembuatan PTK dan publikasi Ilmiah ini. Dengan adanya pelatihan ini diharapkan dapat mengembangkan wawasan para Guruguru SMA khususnya Guru-Guru SMA Negeri 7 Pekanbaru tentang bagaimana caranya membuat publikasi yang baik yang terhindari dari tindakan plagiasme, harapan kedepannya para guru yang mengikuti pelatihan ini dapat melanjutkan kembali ilmu yang mereka dapatkan kepada teman-teman guru yang lain.

\section{METODE PELAKSANAAN}

\footnotetext{
Kegiatan Pelatihan Penulisan Karya Ilmiah dilakukan dengan menggunakan metode seperti berikut.
}

1. Ceramah

Materi yang diberikan adalah penjelasan tentang motivasi untuk menulis karya ilmiah, etika penulisan ilmiah, teknik penulisan karya ilmiah, kebahasaandalam ragam karya ilmiah, penelusuran referensi melalui internet, penyusunan karya ilmiah,dan teknik swasunting.

2. Diskusi

Pada tiap materi yang disampaikan, peserta dapat berdialog danberdiskusi dengan tim pengabdian.

3. Praktek Menulis

Peserta diminta untuk melakukan praktek/latihan menulis. Peserta akan dikelompokkan berdasarkan kemampuan menulis yang telah dimiikinya. Tingkat kesulitan dari praktek ini disesuaikan dengan kemampuan masing-masing perserta.

Pada bagian akhir peserta akan diberi tugas untuk membuat karya tulis berdasarkan bidang keahlian masingmasing. Karya tulis ini merupakan syarat untuk memperoleh sertifikat peserta. Pada penyusunan karya ilmiah ini dilakukan pendampingan oleh fasilitator.

Keterkaitan antara kegiatan yang dilakukan dan berbagai institusi terkait dengan menjelaskan peran dan manfaat yang diperoleh setiap institusi yang terkait

Narasumber yang memberikan pelatihan terdiri dari 7 orang, dengan penanggung jawab bidang masingmasing sebagai berikut: 


\begin{tabular}{|c|c|c|c|}
\hline No & Jenis Kegiatan & Narasumber & Penanggung Jawab \\
\hline 1 & $\begin{array}{l}\text { Pengembangan } \\
\text { Keprofesian } \\
\text { Berkelanjutan dan } \\
\text { Keterkaitannya dengan } \\
\text { Publikasi Ilmiah }\end{array}$ & - Dr. H. Zulkarnain, M.Pd & $>$ Prasetya, M.Si \\
\hline 2 & $\begin{array}{l}\text { Desain Penelitian } \\
\text { Tindakan Kelas }\end{array}$ & - Dra. Hj. Susda Heleni, M.Pd & $>$ Fitra Perdana, M.Si \\
\hline 3 & $\begin{array}{l}\text { Jenis-jenis publikasi } \\
\text { ilmiah }\end{array}$ & $\begin{array}{l}\text { - Rahmiwati Hilma, M.Si } \\
\text { - Rahmadini Syafri, M.Sc }\end{array}$ & $>$ Fitra Perdana, M.Si \\
\hline 4 & \begin{tabular}{lrr} 
Teknik & \multicolumn{2}{c}{ penulisan } \\
jurnal ilmiah dan & dan \\
praktek penulisan &
\end{tabular} & $\begin{array}{l}\text { - Hasmalina Nasution, M.Si } \\
\text { - Prasetya, M.Si } \\
\text { - Dr. Jufrizal Syahri, M.Si }\end{array}$ & $\begin{array}{l}\text { Dr. Sri Hilma Siregar, } \\
\text { M.Sc }\end{array}$ \\
\hline
\end{tabular}

Evaluasi dilakukan berdasarkan kuisioner yang diberikan ke peserta sewaktu pelatihan dan adanya makalah dan draft publikasi yang dibuat oleh peserta pelatihan.

\section{HASIL DAN PEMBAHASAN}

Minat peserta pelatihan penulisan artikel ilmiah ini sangat tinggi, hal ini terlihat dari antusisme peserta mengikuti acara dari pagi sampai sore hari masih penuh semangat. Kegiatan pengabdian kepada masyarakat ini di awali dengan tahap persiapan termasuk konsolidasi tim dan melakukan pertemuan di sekolah dengan wakil kepala sekolah bidang Kurikulum SMA N 7 Pekanbaru, fiksasi jadwal dan tempat dengan pihak SMA N 7 Pekanbaru. Setelah mengadakan pertemuan dengan Kepala Sekolah tim pengabdian masyarakat melakukan pembagian tugas pada masing-masing tim pengabdian masyakat. Tim pengabdian masyarakat melakukan persiapan alat dan bahan yang di perlukan untuk kegiatan pelatihan. diantaranya persiapan ruangan, perlengkapan seminar di antaranya materi seminar, media pelatihan LCD, infocus, makalah serta dokumentasi kegiatan. Sasaran dalam kegiatan pengabdian masyarakat ini adalah guruguru di SMA Negeri 7 Pekanbaru. Berdasarkan hasil kesepakatan dengan Kepala Sekolah Bidang Kurikulum, penyuluhan di lakukan di Aula atau Ruang Rapat SMAN 2 Pekanbaru.

Hasil dari kegiatan pengabdian kepada masyarakat bagi guru-guru SMA N 7 Pekanbaru antara lain :

1. Kegiatan pengabdian masyarakat dilakukan dengan metode ceramah dan diskusi dengan peserta kegiatan dengan peserta pelatihan berjumlah 30 orang guru dari berbagai bidang studi, antara lain : Kimia, Biologi, Fisika, Matematika, TIK, Bahasa Inggris, Geografi, Ekonomi, Sosiologi, Sejarah, Bahasa Indonesia, Agama, dan BK.

2. Secara keseluruhan kegiatan pelatihan yang dilakukan berjalan dengan lancar dan tertib. Pelatihan ini memberikan pengetahuan baru terhadap guru-guru tentang Pengembangan Keprofesian Berkelanjutan dan Keterkaitannya dengan Publikasi Ilmiah tata cara penulisan publikasi ilmiah, Penelitian Tindakan Kelas, Jenisjenis publikasi ilmiah dan Teknik penulisan jurnal ilmiah dan praktek penulisan.Peserta antusias dalam mengikuti pelatihan yang terlihat pada saat kegiatan berlangsung di mana peserta pelatihan berperan aktif dalam sesi diskusi dan tanya jawab.

3. Kegiatan pengabdian kepada masyarakat dilakukan pada hari Sabtu, 10 November 2018 dengan 
tiga tahapan kegiatan. Dimulai dari registrasi peserta, sambutan sekaligus membuka acara pada pukul 08.00 Wib s/d 08.30 wib. Kegiatan kedua pada pukul 09.30 Wib s/d 12.00 wib adalah workshop publikasi ilmiah dan penelitian tindakan kelas yang disampaikan oleh para narasumber yang ahli dibidangnya masing-masing dan tentunya berkaitan dengan judul kegiatan pengabdian. Kegiatan ketiga yaitu praktik teknik penulisan jurnal ilmiah dan praktek penulisannya pembuatan jurnal ilmiah oleh peserta pelatihan. Output yang diharapkan setelah acara adalah, masing-masing peserta memiliki sebuah artikel yang sudah siap untuk di publikasikan dalam jurnal ilmiah.

Tabel 3. Jumlah Peserta Pengabdian Masyarakat di SMAN 7 Pekanbaru

\begin{tabular}{|c|c|c|c|}
\hline No & $\begin{array}{c}\text { Kategori } \\
\text { Kegiatan }\end{array}$ & Jumlah & Persentase \\
\hline 1 & Kegiatan 1 & 30 & $100 \%$ \\
\hline 2 & Kegiatan 2 & 30 & $100 \%$ \\
\hline 3 & Kegiatan 3 & 30 & $100 \%$ \\
\hline
\end{tabular}

Berdasarkan table 3. terlihat bahwa $100 \%$ peserta workshop hadir di setiap kegiatan. Hal ini membuktikan antusiasme dan minat para guru di SMAN 7 Pekanbaru dalam mengikuti pelatihan pembuatan publikasi ilmiah sangat tinggi. Workshop ini telah berhasil dan sukses dilaksanakan di SMAN 7 Pekanbaru, terbukti dengan antusiasme para guru dalam mempraktikkan pembuatan jurnal ilmiahnya masing-masing yang nanti harapannya bisa dipublikasikan baik nasional maupun internasional.

Seluruh peserta antusias dengan kegiatan dan penjelasan yang di berikan oleh narasumber. Adapun Narasumber dalam kegiatan workshop ini adalah 4 orang dengan rincian materi yang disampaikan adalah :

1. Pembicara 1

Menyampaikan materi yang berkaitan dengan Pengembangan Keprofesian

Berkelanjutan dan Keterkaitannya dengan Publikasi Ilmiah dan Jenisjenis publikasi ilmiah

2. Pembicara 2

Menyampaikan materi yang berkaitan dengan desain penelitian tindakan kelas

3. Pembicara 3

Menyampaikan materi yang berkaitan dengan cara merubah laporan penelitian tindakan kelas menjadi jurnal ilmiah atau prosiding.

4. Pembicara 4

Menyampaikan materi yang berkaitan dengan Teknik penulisan jurnal ilmiah dan praktek penulisan

Pada saat kegiatan berlangsung terlihat bahwa para guru di SMAN 7 Pekanbaru belum memahami dengan baik tentang pembuatan jurnal ilmiah dan bagaimana melakukan publikasi ilmiah. Dengan adanya kegiatan pelatihan ini maka diharapkan dapat meningkatkan pemahaman dan kemampuan guru SMAN 7 Pekanbaru dalam membuat, melakukan publikasi ilmiah serta mampu mendesain penelitian tindakan kelas menjadi jurnal ilmiah sehingga tercapai tujuan dari pelatihan pembuatan publikasi ilmiah untuk guru-guru di SMA N 7 Pekanbaru ini.

Hasil kegiatan Pengabdian masyarakat secara garis besar mencakup beberapa komponen sebagai berikut :

1. Keberhasilan target jumlah peserta pelatihan

Target peserta dari kegiatan workshop dan pelatihan ini adalah guru-guru SMAN 7 Pekanbaru dan dalam hal ini tim pengabdian masyarakat telah berhasil 
merangkul guru-guru tersebut untuk ikut serta berpartisipasi dalam acara ini terbukti dengan hadirnya mereka baik disesi pertama dan juga disesi kedua dan kehadirannya melebihi $50 \%$.

2. Tercapainya tujuan pelatihan

Pada dasarnya tujuan dari penyuluhan ini adalah meningkatnya pemahaman dan kemampuan guru terhadap materi pelatihan, yang nantinya dapat digunakan sebagai acuan dalam pembuatan jurnal ilmiah oleh para guru-guru. Guru-guru yang mendapatkan pelatihan diharapkan juga dapat menyebarkan informasi dan membimbing guru-guru lain dalam membuat publikasi ilmiah. Melalui cara ini penyebaran informasi dapat berjalan lebih cepat selain itu dapat melengkapi persyaratan untuk naik pangkat/golongan.

Pada saat pelaksanaan kegiatan terlihat antusiasme peserta dengan berbagai pertanyaan yang dilontarkan oleh peserta. Pada saat klinik proposal, peserta diberikan suatu Lembar Kerja yang berisi isian permasalahan yang mereka temui di dalam kelas, selanjutnya dari Lembar Kerja ini peserta diharapkan dapat menemukan solusi dari permasalahan yang dituangkan dalam sebuah karya ilmiah.

\section{SIMPULAN}

Kegiatan Pelatihan Pembuatan Publikasi Ilmiah bagi Guru di SMAN 7 Pekanbaru mendapat sambutan yang baik dari peserta dan berhasil dengan baik. Keadaan ini dapat dilihat dari kehadiran peserta yang hampir mencapai $100 \%$. Peserta terdiri seluruh guru di SMA N 7 Pekanbaru. karena keterbatasan waktu, tidak semua karya ilmiah dapat terselesaikan oleh sebab itu dilanjutkan secara online, dimana peserta mengirimkan hasil rumusan
Karya Ilmiah yang telah disusun lewat email dan instruktur melakukan review sekaligus revisi jika diperlukan untuk mencapai target luaran dari kegiatan ini.

\section{UCAPAN TERIMAKASIH}

Terima kasih disampaikan kepada Lembaga Penelitian dan Pengabdian Kepada Masyarakat Universitas Muhammadiyah Riau atas bantuan Pendanaan dari kegiatan ini.

\section{DAFTAR PUSTAKA}

[1]. Achmad,Danial. 2004. Kemampuan Membuat Karya Tulis Ilmiah Guru-Guru Sekolah Dasar di Bandar Lampung. Ilmu Pengetahuan Sosial 39(1).

[2]. Aina, M., Bambang H, Retni Sb, Afreni H, Sadikin, A. 2015. Pelatihan Penulisan Karya Tulis Ilmiah Bagi Guru Guru Sma 8 Kota Jambi, Jurnal Pengabdian Pada Masyarakat, Volume 30, Nomor 3 Juli - September 2015.

[3]. Eko Putro Widoyoko. 2008. Penelitian Tindakan Kelas dan Pengembangan Profesi Guru. Disajikan dalam Seminar Nasional Peningkatan Kualitas Profesi Guru Melalui Penelitian Tindakan Kelas. Universitas Muhammadiyah Purworejo. 14 September 2004.

[4]. Hand, B. and V. Prain. 2002. Teachers Implementing Writing To - Learn Strategiesin Junior Secondary Science:A Case Study. Sci Ed 86:737- 755.

[5]. Permenpan dan RB No. 16 Th 2009 Tentang Jabatan Fungsional Guru dan Angka Kreditnya.

[6]. Sri Wening, Nani Ratnaningsih, dan Titin Hera Widi Handayani. 2009. Wokrshop Penulisan Karya Ilmiah sebagai Upaya Pengembangan Profesinalisme 
Guru SMK. Inotek13(2), Agustus 2009

[7]. Suwardi Lubis. 2004. Tehnik

Penulisan Ilmiah Populer.

Universitas Sumatera Utara:

Fakultas Ilmu Sosial dan Ilmu Politik. 